\title{
Results at seven years after the use of intracamerular cefazolin as an endophthalmitis prophylaxis in cataract surgery
}

\author{
Pedro Romero-Aroca ${ }^{1 *}$, Isabel Méndez-Marin², Merce Salvat-Serra², Juan Fernández-Ballart ${ }^{3}$, Matias Almena-Garcia ${ }^{2}$ \\ and Javier Reyes-Torres²
}

\begin{abstract}
Background: To evaluate results after seven years using prophylactic intracameral cefazolin for the prevention of endophthalmitis in cataract surgery.

Methods: A prospective, observational study of all patients submitted to cataract surgery over the period January 1996 to December 2009. All cases of postoperative endophthalmitis over that period were reviewed. The patients were classified in two groups: Group 1 (11,696 patients) operated on between January 1996 and December 2002, Group 2 (13,305 patients) between January 2003 and December 2009 (in whom a 1 mg/0.1 bolus of intracameral cefazolin was instilled).
\end{abstract}

Results: During the study period, 76 cases of endophthalmitis were observed in Group 1, and seven in Group 2. The rate of postoperative endophthalmitis reduced from $0.63 \%$ to $0.05 \%$ with a cefazolin injection. The relative risk (RR) for endophthalmitis in Group 1 against group 2 was 11.45 [95\% Cl 5.72-22.84, $p<0.001]$.

Conclusions: An intracameral bolus injection of cefazolin (1 $\mathrm{mg}$ in $0.1 \mathrm{ml}$ solution) at the conclusion of the cataract surgery significantly reduced the rate of postoperative endophthalmitis.

Keywords: endophthalmitis, cataract surgery, cefazoline, prophylactic ophthalmic surgery, cephalosporines

\section{Background}

Endophthalmitis remains a serious complication after cataract surgery, although prophylactic measures introduced in recent years have reduced the number of patients with this complication.

Currently there are two streams of opinion towards endophthalmitis prophylaxis, the use of fourth-generation quinolones (gatifloxacin and moxifloxacin) topically [1-4], or the introduction of intracameral cephalosporins, the latter being cefuroxime (a second generation cephalosporin), which is the most widely used and accepted [5-10]. However, our study group [11], as well as Garat et al [12,13], prefers the use of cefazolin (a first generation cephalosporin). Having previously studied the bacteria that cause endophthalmitis in our environment most frequently, we

\footnotetext{
* Correspondence: romeropere@gmail.com

'Professor of Ophthalmology. Ophthalmology Service. Hospital Universitari

Sant Joan, IISPV, Universidad Rovira i Virgili, Reus (Spain

Full list of author information is available at the end of the article
}

prefer cefazolin because of its higher frequency of grampositive bacteria in our medium, and because it best covers infections by such bacteria. Furthermore, cefazolin shows no corneal toxicity at doses of $1 \mathrm{mg}$ or $2 \mathrm{mg}$; its toxicity was established when doses of $5 \mathrm{mg}$ or more were injected. We consider the risk of an infection caused by a cefazolin-resistant bacterium low, based on the bacteria cultured since 1994 and their antibiogram. We consider there not to be any risk of coverage of gram-negative bacteria by cefazolin, and its incidence in endophthalmitis was low in our Health Care District.

Our two groups are included in the Barcelona Endophthalmitis Group (GEB), formed by 38 public and private Hospitals in Catalonia (Spain), who have been studying the epidemiological factors of postoperative endophtalmitis and assessing the prophylaxis and treatment of endophtalmitis in our country since 2000. Appendix 1 gives a list of GEB participating hospitals and ophthalmologists.

\section{() Biomed Central}


This study will present the results obtained after seven years of using intracameral cefazolin after cataract surgery at doses of $1 \mathrm{mg}$ in $0.1 \mathrm{ml}$.

\section{Methods}

Since 1996, there has been an ongoing registration of all postoperative endophthalmitis patients at Hospital St Joan (Table 1). All cases of postoperative endophthalmitis were studied in the epidemiological unit of the hospital in order to determine their origin.

\section{Design}

A prospective observational study. The population comprised all patients submitted to un-combined cataract surgery in the period from January 1996 to December 2009. All cases of postoperative endophthalmitis were related. Only patients with phacoemulsification were included in the study in order to reduce any possible bias introduced by the technical cataract surgery. Technical surgery includes a sutureless, clear corneal incision of $3.2 \mathrm{~mm}$ using a venturi (Millenium, Bausch Lomb ${ }^{\circledR}$ ) phaco unit.

For all patients included in our hospital, the prophylactic measures for reducing the bacterial flora of the conjunctiva since 1996 were:

- Topical $10 \%$ povidone-iodine in the skin of periorbital region

- Topical 5\% povidone-iodine on the conjunctiva and eyelashes for a minimum of 1 minute

- Draping of the peri-orbital region and eyelashes

- Postoperative use of eye drops with tobramycin $3.00 \mathrm{mg} / \mathrm{mL}$ associated to dexametasone $1.00 \mathrm{mg} /$ $\mathrm{mL}$ instilled every 4 hours (these eye drops were gradually tapered after 1 week), and diclofenac every 6 hours. These drops were continued at week 3 , and the topical diclofenac was used for 1 month after surgery.
The patients were classified in two groups:

- Group 1 included patients operated on from January 1996 to December 2002 (11696 patients), during which time intracameral cefazolin was not used.

- Group 2 included patients operated on from January 2003 to December 2009 (13305 patients) when we used $1.00 \mathrm{mg} / 0.1 \mathrm{~mL}$ intracamerular cefazolin was used at the end of cataract surgery.

\section{Antibiotic selection}

The choice of cefazolin as an intracameral antibiotic was based on bacterial and antibiogram studies in endophthalmitis cases since 1996 (Table 2), and the antibiogram (Table 3).

Table 3 was created from the analysis of an antibiogram of 14,626 cultures obtained from samples of patients with community- and hospital- acquired infections (urinary infections, pneumonia, sepsis, etc.), which occurred during 2002 in the population serviced by our Health Care District. In the table we presented only the results obtained with the bacteria cultured in endophthalmitis observed in our area, and compared with the prophylactic antibiotics most frequently used for endophthalmitis in Spain (cefazolin, cefuroxime, vancomicyn, and levofloxacin). At this point we should point out that in our Hospital in cases of allergy to cephalosporines we used vancomicyn.

The dose of cefazolin $(1 \mathrm{mg} / 0.1 \mathrm{ml})$ was based on our calculations that this anterior chamber concentration of cefazolin exceeded the minimum inhibitory concentration (MIC) for susceptible bacteria.

\section{Inclusion criteria}

Patients in our dependent Health care district who were submitted to cataract surgery by phacoemulsification by clear cornea incision.

Table 1 Description of cases of endophthalmitis since 1996

\begin{tabular}{|c|c|c|c|c|c|c|c|c|}
\hline $\begin{array}{l}\text { Group 1 } \\
1996-2002 \\
\end{array}$ & & & & & & & & \\
\hline & 1996 & 1997 & 1998 & 1999 & 2000 & 2001 & 2002 & Total \\
\hline Cases* $^{*}$ & 8 & 9 & 9 & 11 & 12 & 13 & 14 & 76 \\
\hline Percentage & $0.637 \%$ & $0.613 \%$ & $0.629 \%$ & $0.664 \%$ & $0.634 \%$ & $0.687 \%$ & $0.692 \%$ & $0.649 \%$ \\
\hline Number of operations** & 1256 & 1467 & 1430 & 1656 & 1892 & 1972 & 2023 & 11696 \\
\hline \multicolumn{9}{|l|}{ Group 2 2003-2009 } \\
\hline Cases* & 1 & 1 & 1 & 0 & 2 & 1 & 1 & 7 \\
\hline Percentage & $0.058 \%$ & $0.052 \%$ & $0.055 \%$ & $0.000 \%$ & $0.101 \%$ & $0.050 \%$ & $0.049 \%$ & $0.052 \%$ \\
\hline Number of operations** & 1707 & 1911 & 1812 & 1874 & 1967 & 1997 & 2037 & 13305 \\
\hline
\end{tabular}

Cases $^{*}=$ number of cases of endophthalmitis (proven + unproven) occurring each year

Patients ${ }^{* *}=$ Number of cataract interventions carried out each year 
Table 2 Bacteria cultured in cases of endophthalmitis in the two groups.

\begin{tabular}{lll}
\hline & $\begin{array}{l}\text { Number of } \\
\text { cases } \\
\text { (percentage) } \\
\mathbf{1 9 9 6 - 2 0 0 2}\end{array}$ & $\begin{array}{l}\text { Number of } \\
\text { cases } \\
\text { (percentage) } \\
\mathbf{2 0 0 3 - 2 0 0 9}\end{array}$ \\
\hline Negative cultures & $26(34.21 \%)$ & $2(28.57 \%)$ \\
\hline Gram positive (96.00\%) & $37(74.00 \%)$ & \\
\hline Staphylococcus epidermidis & $5(10.00 \%)$ & \\
\hline Staphylococcus aureus methicillin & $2(4.00 \%)$ & \\
sensible & $1(2.00 \%)$ & \\
\hline Streptococcus pneumoniae & $3(6.00 \%)$ & \\
\hline Streptococcus & & \\
viridans & & $1(14.28 \%)$ \\
\hline Bacillus spp & $1(2.00 \%)$ & $1(14.28 \%)$ \\
\hline Corynebacterium & $1(2.00 \%)$ & $2(28.57 \%)$ \\
\hline Gram negative (4.00\%) & & \\
\hline E Colli & & \\
\hline Serratia marcensens & & \\
\hline Klebsiella pneumoniae & & \\
\hline Pseudomona aeroginosa & & \\
\hline Proteus mirabilis & & \\
\hline
\end{tabular}

Table 3 Sensitivity to antibiotics of the most frequent bacteria in our Area in $\mathbf{2 0 0 2}$

\begin{tabular}{lllll}
\hline Germen & Cefazolin & Cefuroxime & Levofloxacin & Vancomicyn \\
\hline Gram positive & & & & \\
\hline Staphilococcus & $100 \%$ & $96 \%$ & $65 \%$ & $66 \%$ \\
Aureus & $(\leq 2 \geq 4)^{*}$ & $(\leq 2 \geq 4)$ & $(\leq 0.5 \geq 8)$ & $(\leq 4 \geq 32)$ \\
\hline Staphilococcus & $54 \%$ & $48 \%$ & $17.64 \%$ & $99,02 \%$ \\
Aureus & $(\leq 2 \geq 4)$ & $(\leq 2 \geq 4)$ & $(\leq 0.5 \geq 8)$ & $(\leq 4 \geq 32)$ \\
MARSA & & & & \\
\hline Staphilococcus & $100 \%$ & $97 \%$ & $27 \%$ & $97 \%$ \\
Epidermidis & $(\leq 2 \geq 4)$ & $(\leq 2 \geq 4)$ & $(\leq 0.5 \geq 8)$ & $(\leq 4 \geq 32)$ \\
\hline Streptococcus & $96 \%$ & $79.15 \%$ & $89 \%$ & $100 \%$ \\
Pneumoniae & $(\leq 2 \geq 8)$ & $(\leq 0.12 \geq 2)$ & $(\leq 2 \geq 8)$ & $(\leq 1-\mathbf{f} *)$ \\
\hline Gram negative & & & & \\
\hline E. Colli & $85 \%$ & $87 \%$ & $71 \%$ & $90 \%$ \\
& $(\leq 4 \geq 32)$ & $(\leq 4 \geq 32)$ & $(\leq 0.5 \geq 8)$ & $(\leq 4 \geq 32)$ \\
\hline Pseudomona & $18 \%$ & $15 \%$ & $65 \%$ & $65 \%$ \\
Aeroginosa & $(\leq 4 \geq 32)$ & $(\leq 4 \geq 32)$ & $(\leq 2 \geq 8)$ & $(\leq 4 \geq 32)$ \\
\hline Proteus & $79 \%$ & $82 \%$ & $70 \%$ & $100 \%$ \\
Mirabilis & $(\leq 4 \geq 32)$ & $(\leq 4 \geq 32)$ & $(\leq 0.5 \geq 8)$ & $(\leq 4 \geq 32)$ \\
\hline Klebsiella & $75 \%$ & $79 \%$ & $100 \%$ & $95 \%$ \\
Pneumoniae & $(\leq 4 \geq 32)$ & $(\leq 4 \geq 32)$ & $(\leq 0.5 \geq 8)$ & $(\leq 4 \geq 32)$ \\
\hline
\end{tabular}

$(\leq 2 \geq 4)^{*}=$ MIC (minimum inhibitory concentration) = Critical concentrations in $\mu \mathrm{g} / \mathrm{ml}$ (critical concentration of susceptibility, critical concentration of resistance), according to the recommendations of MENSURA to the interpretation of antibiogram.

$\mathrm{f}^{*}=$ Unknown, we do not know the mechanisms of resistance, or the measure for resistance.

\section{Exclusion criteria}

Patients admitted for extracapsular cataract surgery. Patients allergic to cephalosporins and to whom we gave intracamerular vancomicyn.

\section{Ethics}

Local ethics committee approval the study CEIC HUSJ2002-DEC-1022

\section{Definition of acute postoperative endophthalmitis}

Following the criteria [14] in the Endophthalmitis Vitrectomy Study (EVS), the ophthalmologist diagnosed presumed acute endophthalmitis. If a positive culture of a vitreous sample was obtained, we defined the case as a proven acute endophthalmitis. In all proven and unproven cases, the patients had swollen lids, pain and an opaque vitreous.

\section{Microbiological method}

Vitreous samples obtained by the ophthalmologist were immediately processed, then a Gram stain was carried out and the sample cultivated in petri dishes. Antibiogram susceptibility was measured according to the criteria laid down by the Spanish Committee for the Standardization of the Sensitivity and Resistance to Antimicrobials (MENSURA) [15-17] which includes members of the Spanish Society of Chemotherapy and the Spanish Society for Infectious Diseases and Microbiology [15]. This is a body with responsibilities similar to those of the National Committee for Clinical Laboratory Standards [18].

Statistical analyses for descriptive statistics were performed using SPSS statistical software (version 17.0). The data obtained was analysed with frequency and descriptive statistics. Values are expressed as mean \pm SEM, and statistical significance was determined using the Student's t-test for paired data.

\section{Results}

Demographic results in the two groups of patients

Group 1. Formed by patients without intracameral instillation of cefazolin. This group included a total of 11,696 patients, with a median age of $69.8 \pm 7.55$ years (53-89 years); a total of 6785 (58.01\%) were females. Group 2. Formed by patients with intracameral instillation of cefazolin at doses of $1 \mathrm{mg} / 0.1 \mathrm{~mL}$. This group included a total of 13,305 patients, with a median age of $66.17 \pm 7.83$ years (53-81 years); a total of 7717 (58.00\%) were females. The difference between groups was not statistically significant in the Student's t-test.

\section{Endophthalmitis cases}

In Group 1 there were 76 postoperative endophthalmitis cases, at a median elapsed time of $5.37 \pm 2.33$ days after 
surgery. In 16 (69.77\%) cases, cultures were positive for the following sub-classified gram-positive cultured bacteria: 9 cases (39.13\%) of Staphylococcus epidermidis, 4 cases (17.39\%) of staphylococcus aureus and 2 cultures $(8.70 \%)$ positive for Streptococcus spp. The gram-negative bacteria gave a culture positive for Klebsiella pneumoniae (4.35\%). Group 2, there were seven postoperative endophthalmitis cases, oat a median elapsed time of $5.41 \pm 2.29$ days after surgery. The statistical study of differences in respect to first group were significant at $\mathrm{p}<0.001$, RR: 11.45 [95\% CI 5.72-22.84].

The bacteria cultured were:

- The first case involved patients with diabetes mellitus type II, treated with insulin for 30 years, with macro vascular disease with symptoms of intermittent claudication. The culture was positive for a Gram-negative bacterium (Klebsiella pneumoniae).

- The second case was a patient who lived alone and who had serious social problems; the patient also had domestic animals at home. The culture was positive for a Gram-positive anaerobic bacterium (Corynebacterium).

- The third case, positive for Proteus mirabilis, occurred in a 68-year-old woman with type II diabetes mellitus of long evolution (22 years), with poor glycaemic control and peripheral vascular macroangiopathy.

- The fourth case, positive for Proteus mirabilis, occurred in a 77-year-old man with type II diabetes mellitus and poor glycaemic control.

- The fifth case, positive for Pseudomona aeroginosa, occurred in a 73-year-old man with viral C-hepatitis.

- Negative cultures: two cases of negative cultures (28.57\%) were observed in this period of time.

In the groups of patients that received intracamerular cefazolin, there were no cases observed of toxic effect at the corneal or retina levels, nor was there any hypersensitivity reaction.

\section{Statistical analysis}

The relative risk for presenting with endophthalmitis in Group 1 compared with Group 2 was 11.45 [95\% CI $5.72-22.84, \mathrm{p}<0.001]$. When limiting the analysis to proven cases (50 cases in Group 1, against 5 cases in Group 2), the estimators of the relative risk were 14.07 [95\% CI $7.68-24.48, \mathrm{p}<0.001]$.

\section{Visual acuity}

1. In Group 1 (period 1996-2002) 38 over 76 patients (50\%) had a final visual acuity (VA) over 0.1 and six patients (7.9\%) had VA $>0.4$ on the Snellen charts. There were ten patients with no light perception (four cases with negative culture, one case produced by Seratia marcensens, and five cases of Streptococcus pneumoniae). Staphilococcus epidermidis in 18 cases caused a final VA between 0.1 and
0.4 , and in 14 cases a final VA between light perception and 0.1 ; the Staphilococcus aureus predominantly produced a final VA between light perception and 0.1 (four cases) and only one case with final VA $>0.4$ on the Snellen charts (Table 4).

2. In Group 2 (period 2003-2009) four patients had final VA of no light perception (two cases with gram-negative bacteria, one case with negative culture and one case produced by gram-positive corynebacterium). In the other three cases, the final VA was inferior to 0.1 on the Snellen charts (two cases with gram-negative bacteria and one with a negative culture) (Table 4).

\section{Discussion}

In our health care district we had a high level of endophthalmitis. Previously, the intracamerular use of antibiotics, as we point out in the present study in group 1, lead to the incidence of endophthalmitis at a rate of $0.649 \%$. This value is higher than that reported in other countries $[2,6,8,14]$, but the incidence in Spain was also higher than other study groups, Garcia-Saenz et al [19] found an incidence of 0.59\% (95\% CI, 0.50\%$0.70 \%$ ) between January 1999 and September 2005, and Garat et al showed an incidence of $0.422 \%$ (95\% CI $0.279-0.613)$ in their studies [12,13]. Because our centre had an excessive number of endophthalmitis cases despite using all means of regular prophylaxis (a sterile ophthalmology operating room, povidone-iodine in skin (at 10\%) and conjunctival sac (at 5\%) with few surgical intraoperative complications etc.), we decided to use intracamerular antibiotics after cataract surgery.

Peyman et al. published the first report of successful prophylactic bolus injections of antibiotics into the anterior chamber in 1977 [20]. Despite the efficacy of the injections, the technique later becomes forgotten about. It is well-established that the source of most infecting agents is the patients' ocular flora; the most frequently reported being bacteria gram-positive, coagulase-negative, or positive staphylococcus.

Swedish physicians have pioneered the use of intracameral cefuroxime since 2002, with excellent outcomes in 400,000 surgical interventions. Montan et al. published the efficacy of cefuroxime $1 \mathrm{mg}$ intracameral $[5,6]$, a practice that has lowered the rate of postoperative endophthalmitis from $0.26 \%$ to $0.06 \%$. The large, prospective, multi-centred study, the European Society of Cataract Refractive Surgeons (ESCRS) confirmed the Swedish experience, finding that an injection of cefuroxime at the end of the surgery reduced endophthalmitis rates to just $0.05 \%$ [8-10].

We chose to use cefazolin, which is recommended by the Department of Microbiology and the Infectious 
Table 4 Final visual acuity in patients with endophthalmitis.

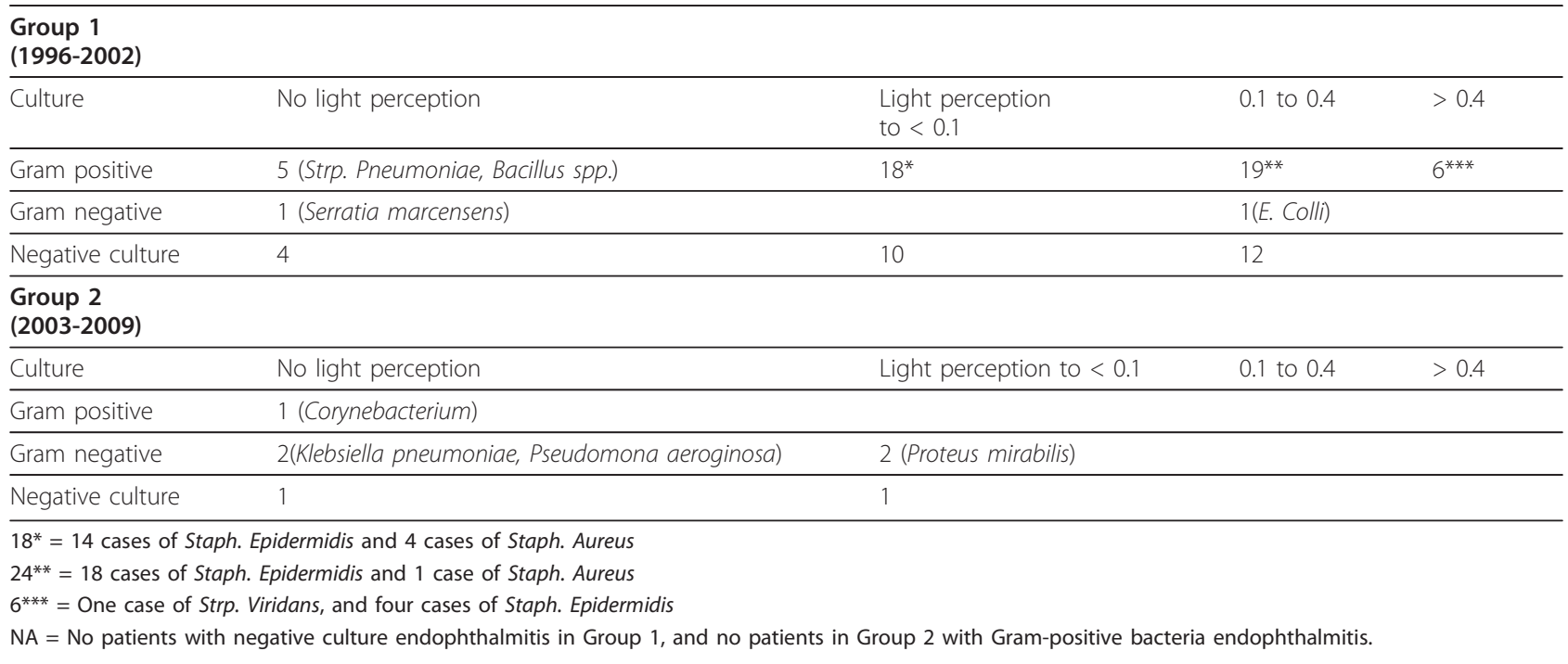

Diseases Committee of our Hospital, rather than cefuroxime because it is a first generation cephalosporin and has a wide range of activity against gram-positive bacteria in our Health Care District, rather than a secondgeneration cephalosporin, such as cefuroxime. A study in our Health Care District by Vila-Corcoles et al [21], showed an increased resistance of Streptococcus pneumoniae to cefuroxime but not to cefazolin.

It is interesting to observe in Table 3 that cefazolin and cefuroxime present a similar antibiotic resistance pattern, with regard to both gram-positive and gramnegative bacteria. Therefore, we still believe that cefazolin is a good option as a prophylaxis for endophthalmitis, and its substitution for cefuroxime is not important for reducing the number of cases of endophthalmitis. However, by using cefazolin, there is still a risk of infection by gram-negative bacteria, which is why the majority of proven cases of endophthalmitis in Group $2(4 / 5$ cases were gram-negative) were caused by this type of bacteria. This is clearly a limitation in the use of cefazolin as a prophylaxis for endophthalmitis.

The lack of availability of eye-drops of fourth-generation quinolones in Spain is the most obvious reason for the preference for intracamerular antibiotics in the prophylaxis of endophthalmitis. Since June 2010, a moxifloxacin eye-drop has been available in Spain, with more possibilities of prophylaxis.

Results show that final VA was worse in Group 2 than in group 1. The explanation for this can be found in the type of bacteria that cause endophthalmitis. We found Corynebacterium, Klebsiella pneumonia, Pseudomona aeroginosa, and Proteus mirabilis in group 2. All these bacteria were poorly sensitive to cefazolin. Negative culture was observed in a $34.21 \%$ of cases in group 1 and $28.57 \%$ in Group 2, similar to other studies, such as the
Endophthalmitis Vitrectomy Study (EVS), with values near to $30 \%$.

\section{Conclusions}

Intracameral bolus injection of cefazolin in cataract surgery demonstrated prophylactic efficacy in diminishing the rate of postoperative endophthalmitis in our hospital, at two doses of $1 \mathrm{mg}$ in $0.1 \mathrm{ml}$ solution.

Furthermore, a close relationship between with the Department of Microbiology, and the Infectious Diseases Committee of our Hospital is essential for developing a proper antibiotic prophylaxis.

Further studies are needed with a larger number of patients in order to fully determine the effectiveness of cefazolin and its non-toxicity at corneal endothelium level.

\section{Appendix 1}

Hospitals that form the Barcelona Endophtalmitis Group (GEB). http://gebcn.org/geb.html

01. Hospital Sant Pau: Dr. Jesus Diaz

02. Hospital Clínic: Dra. Socorro Alforja - Dr. Joan Giralt

03. Hospital Bellvitge: Dr. Marc Rubio

04. Hospital Vall d'Hebron: Dr. Alex Fonollosa

05. Hospital General d'Hospitalet: Dra. Magela Garat

06. Hospital Germans Trias i Pujol (Can Ruti): Dr. Anglada

07. Hospital Parc Taulí: Dr. D. Muntaner - Dra. Ma'T.

Sellarés - Dra. C. Guardia

08. Mutua de Terrassa: Dra. Silvia Freixes

09. IMAS (H. Esperança i Mar): Dr. Daniel Vilaplana Dr. Poposki

10. Hospital St. Rafael: Dra. Ciprés

11. Hospital Viladecans: Dr. Sergi Sedó 
12. Institut Català de la Retina: Dra. Sust

13. Institut Oftalmic de Barcelona: Dra. Laura Sararols 14. Instituto de Microcirugia Ocular: Dra. Isabel Nieto - Dra. Elena Arrondo

15. Hospital General de Catalunya: Dr. Rouras

16. Clínica Barraquer: Dr. Remberto Escoto

17. Hospital Espirit Sant: Dr. Rouras - Dr. Amias

18. Hospital Granollers: Dr. Jarek Hernecki

19. Hospital de Terrassa: Dr. Jose Juan Escobar - Dr. Jose Pradas

20. Institut Condal d'Oftalmologia (ICO): Dra. Sararols

21. Hospital Municipal de Badalona: Dra. Estela Barnola

22. OFTALMO: Dr. J. Cabot

23. Clínica de Vic i Hospital General de Vic: Dr. Manuel Amén

24. Consulta GMOftalmo: Dr. Gallofré

25. Hospital de Nens de Barcelona: Dr. J. Flors Despranell

26. Clinica Quiron: Dr. Aureli Rilo

27. Institut Oftalmológic Tres Torres: Dr. Emili Juarez

28. Hospital de Mollet: Dr. Francisco Goñi

29. Hosp. Universitari Josep Trueta: Dra. Flor Escalada

30. Hosp. Universitari Sant Joan de Reus: Dr. Pere Romero Dra. Isabel Mendez

31. Hosp. Universitari Joan XXIII Tarragona: Drs. Perez i Pardo

32. Hosp Verge de la Cinta de Tortosa: Dr. J Colome

33. Hosp Son Dureta, Palma de Mallorca: Dr. José Luis Olea

34. Clinica Sagrada Familia i Corachan: Dr. Carlos Martin

35. Clínica Plató: Dr. Joan Pujol - Dr. Sergi Miserachs

36. Institut Oftalmológic de Menorca: Dr. Pere Vilallonga

37. Hospital Sant Joan de Deu de Martorell: Dra. Ma Carmen del Aguila

38. CEM (Centro Especializado Microcirugía): Dra. Laura Sararols

\section{Author details}

${ }^{1}$ Professor of Ophthalmology. Ophthalmology Service. Hospital Universitari Sant Joan, IISPV, Universidad Rovira i Virgili, Reus (Spain. ${ }^{2}$ Ophthalmology Service. Hospital Universitari Sant Joan, IISPV, Universidad Rovira i Virgili, Reus (Spain. ${ }^{3}$ Department of Basic Sciences, University Rovira i Virgili, Tarragona (Spain). CIBER Fisiopatología de la Obesidad y Nutrición (CIBEROBN), Instituto de Salud Carlos III (ISCIII), (Spain.

\section{Authors' contributions}

PRA contributed to the study design, the researched data analysis, the Discussion, manuscript writing and supervision of the manuscript. IMM contributed to ophthalmologic data collection, contributed to the Discussion, made a critical review, and edited the manuscript. MAG contributed to the study design, systemic disease diagnosis and laboratory analysis interpretation, the researched data analysis and the Discussion. JRT contributed to the ophthalmologic data collection, and the researched data interpretation. JFB contributed to the statistical analysis, the researched data interpretation, and contributed to the interpretation of the study findings. All authors read and approved the final manuscript.

\section{Competing interests}

The authors report no conflicts of interest. The authors alone are responsible for the content and writing of the paper. No financial support was received.

Received: 19 January 2011 Accepted: 24 January 2012

Published: 24 January 2012

\section{References}

1. Jensen MK, Fiscella RG, Moshirfar M, Mooney B: Third- and fourth generation fluoroquinolones: retrospective comparison of endophthalmitis after cataract surgery performed over 10 years. J Cataract Refract Surg 2008, 34:1460-7.

2. O'Brien TP, Arshinoff SA, Mah FS: Perspectives on antibiotics for postoperative endophthalmitis prophylaxis: potential role of moxifloxacin. J Cataract Refract Surg 2007, 33:1790-800.

3. Kowalski RP, Romanowski EG, Mah FS, Yates KA, Gordon YJ: Topical $0.5 \%$ moxifloxacin prevents endophthalmitis in an intravitreal injection rabbit model. J Ocul Pharmacol Ther 2008, 24:1-7.

4. Hariprasad SM, Blinder KJ, Shah GK, Apte RS, Rosenblatt B, Holekamp NM, Thomas MA, Mieler WF, Chi J, Prince RA: Penetration pharmacokinetics of topically administered $0.5 \%$ moxifloxacin ophthalmic solution in human aqueous and vitreous. Arch Ophthalmol 2005, 123:39-44.

5. Montan PG, Wejde G, Koranyi G, Rylander M: Prophylactic intracameral cefuroxime. Efficacy in preventing endophthalmitis after cataract surgery. J Cataract Refract Surg 2002, 28:977-81.

6. Montan P, Lundström M, Stenevi U, Thorburn W: Endophthalmitis following cataract surgery in Sweden: national prospective survey 19992001. In Acta Ophthalmol Scand Edited by: Wejde G 2005, 83:7-10.

7. García-Sáenz MC, Arias-Puente A, Rodríguez-Caravaca G, Bañuelos JB: Effectiveness of intracameral cefuroxime in preventing endophthalmitis after cataract surgery Ten-year comparative study. J Cataract Refract Surg 2010, 36:203-7

8. ESCRS study of prophylaxis of postoperative endophthalmitis after cataract surgery: Case for a European multicenter study, Seal DV, Barry P, Gettinby G, Lees F, Peterson M, Revie CW, Wilhelmus KR: ESCRS Endophthalmitis Study Group. J Cataract Refract Surg 2006, 32:396-406, Erratum in: J Cataract Refract Surg. 2006,32:709

9. ESCRS study of prophylaxis of postoperative endophthalmitis after cataract surgery: Preliminary report of principal results from a European multicenter study, Barry P, Seal DV, Gettinby G, Lees F, Peterson M, Revie CW: ESCRS Endophthalmitis Study Group. J Cataract Refract Surg 2006, 32:407-10.

10. ESCRS Endophthalmitis Study Group: Prophylaxis of postoperative endophthalmitis following cataract surgery: results of the ESCRS multicenter study and identification of risk factors. J Cataract Refract Surg 2007, 33:978-88

11. Romero P, Méndez I, Salvat M, Fernández J, Almena M: Intracameral cefazolin as prophylaxis against endophthalmitis in cataract surgery. J Cataract Refract Surg 2006, 32:438-41.

12. Garat M, Moser CL, Alonso-Tarrés C, Martín-Baranera M, Alberdi A Intracameral cefazolin to prevent endophthalmitis in cataract surgery: 3-year retrospective study. J Cataract Refract Surg 2005, 31:2230-4.

13. Garat M, Moser CL, Martín-Baranera M, Alonso-Tarrés C, Alvarez-Rubio L: Prophylactic intracameral cefazolin after cataract surgery: endophthalmitis risk reduction and safety results in a 6-year study. J Cataract Refract Surg 2009, 35:637-42.

14. Endophthalmitis vitrectomy study group: Result of the endophthlmitis vitrectomy study. A randomised trial of immediate vitrectomy and of intravenous antibiotics for the treatment of postoperative bacterial endophthalmitis. Arch Ophth/mol 1995, 1:1479-96.

15. Peter Barry, Susanne Gardner, David Seal, George Gettinby, Fiona Lees, Magnus Peterson, Crawford Revie, for the ESCRS Endophthalmitis Study Group: Clinical observations associated with proven and unproven cases in the ESCRS study of prophylaxis of postoperative endophthalmitis after cataract surgery. J Cataract Refract Surg 2009, 35:1523-31.

16. Baquero F, Martínez-Beltrán J, Cantón R, Grupo MENSURA: Criterios del grupo MENSURA para la definición de los puntos críticos de sensibilidad a los antibióticos. Rev Esp Quimiot 1997, 10:303-13. 
17. Baquero F, Martínez-Beltrán J, Cantón R: y los restantes miembros de la Mesa Española de Normalización de la Sensibilidad y Resistencia a los Antimicrobianos (MENSURA). Criterios del grupo MENSURA para la definición de los puntos críticos de sensibilidad a los antibióticos. Enf Infec Microbiol Clin 1998, 16:85-92.

18. National Committee for Clinical Laboratory Standards: Performance Standards for Antimicrobial Disk Susceptibility Tests: Approved Standard. NCCLS document M2-A7. Edited by: Wayne, PA. National Committee for Clinical Laboratory Standards; 72002.

19. García-Sáenz MC, Arias-Puente A, Rodríguez-Caravaca G, Andrés Alba Y, Bañuelos Bañuelos J: Endophthalmitis after cataract surgery: epidemiology, clinical features and antibiotic prophylaxis. Arch Soc Esp Oftalmol 2010, 85:263-7.

20. Peyman GA, Sathar ML, May DR: Intra ocular gentamicine as intra operative prophylaxis in South India eye camps. Br J Ophthalmol 1977, 61:260-2.

21. Angel Vila-Corcoles, Ferran Bejarano-Romero, Elisabeth Salsench, Olga Ochoa-Gondar, Cinta de Diego, Frederic Gomez-Bertomeu, Xavier Raga-Luria, Xavier Cliville-Guasch, Victoria Arija: Drug-resistance in Streptococcus pneumoniae isolates on Spanish middle aged and older adults with community-acquire pneumonia. BMC Infectious Diseases 2009, 9:36-43.

\section{Pre-publication history}

The pre-publication history for this paper can be accessed here: http://www.biomedcentral.com/1471-2415/12/2/prepub

doi:10.1186/1471-2415-12-2

Cite this article as: Romero-Aroca et al:: Results at seven years after the use of intracamerular cefazolin as an endophthalmitis prophylaxis in cataract surgery. BMC Ophthalmology 2012 12:2.

\section{Submit your next manuscript to BioMed Central and take full advantage of:}

- Convenient online submission

- Thorough peer review

- No space constraints or color figure charges

- Immediate publication on acceptance

- Inclusion in PubMed, CAS, Scopus and Google Scholar

- Research which is freely available for redistribution

Submit your manuscript at www.biomedcentral.com/submit
Biomed Central 